Abstracta Iranicacta Iranica

Revue bibliographique pour le domaine irano-aryen

Volume 32-33 | 2013

Comptes rendus des publications de 2009-2010

\title{
Andrea Gariboldi. Sasanian Coins and History. The Civic Numismatic Collection of Milan
}

\section{Rika Gyselen}

\section{(2) OpenEdition}

1 Journals

Édition électronique

URL : http://journals.openedition.org/abstractairanica/40491

DOI : 10.4000/abstractairanica.40491

ISSN : 1961-960X

\section{Éditeur :}

CNRS (UMR 7528 Mondes iraniens et indiens), Éditions de l'IFRI

\section{Édition imprimée}

Date de publication : 1 décembre 2013

ISSN : 0240-8910

\section{Référence électronique}

Rika Gyselen, «Andrea Gariboldi. Sasanian Coins and History. The Civic Numismatic Collection of Milan », Abstracta Iranica [En ligne], Volume 32-33 | 2013, document 153, mis en ligne le 01 juillet 2016,

consulté le 26 septembre 2020. URL : http://journals.openedition.org/abstractairanica/40491 ; DOI : https://doi.org/10.4000/abstractairanica.40491

Ce document a été généré automatiquement le 26 septembre 2020.

Tous droits réservés 


\title{
Andrea Gariboldi. Sasanian Coins and History. The Civic Numismatic Collection of Milan
}

\author{
Rika Gyselen
}

\section{RÉFÉRENCE}

Andrea Gariboldi. Sasanian Coins and History. The Civic Numismatic Collection of Milan. Mazda Publisher Costa Mesa California, 2010, 130 p. (including 20 plates). [Sasanika Series, No. 3]

1 Ce livre présente une édition revisée en anglais d'un petit ouvrage publié en 2003 en italien La monetazione sasanide nelle Civiche Raccolte Numismatiche di Milano. La publication du catalogue de cette petite collection de 69 monnaies a été l'occasion pour l'A. d'aborder plusieurs aspects du monnayage sassanide: a) Monnayage et l'art des Sassanides à travers l'analyse de leurs couronnes, b) L'iconographie monétaire, c) Les numéraires et les poids, d) Les ateliers et la circulation monétaires, e) Les légendes monétaires. Étant donné la complexité de beaucoup de ces sujets, et le peu de pages qui y sont consacrées, l'A. a insisté sur certains aspects, laissant d'autres peu commentés. Il est très probable que ce livre était sous presse depuis déjà plusieurs années, du moins c'est ce que les références bibliographiques semblent indiquer. Au cours de ces dernières années ont été produites plusieurs études approfondies dont l'A. n'a donc pas pu tenir compte pour sa démonstration. 


\section{AUTEURS}

\section{RIKA GYSELEN}

CNRS/Mondes iranien et indien, Paris 